\title{
IAMJ
}

INTERNATIONAL

AYURVEDIC

MEDICAL JOURNAL

\section{EVALUATION OF MARMA POINT STIMULATION IN AVABAHUKA WITH RESPECT TO PERIARTHRITIS SHOULDER}

\author{
Neha Sharma', Gaurav Parmar $^{2}$, Anil Dutt ${ }^{3}$ \\ ${ }^{1} \mathrm{MS}$ (Ayu) Scholar, Department of Shalya Tantra \\ ${ }^{2}$ MS (Ayu), Department of Shlaya Tantra \\ ${ }^{3}$ Prof. MS (Ayu) Department of Shalya Tantra \\ Rajiv Gandhi Government Post-Graduate Ayurvedic College Paprola, Kangra (HP), India 176115
}

Corresponding Author: snehpundrik2310@gmail.com

\section{https://doi.org/10.46607/iamj5409092021}

(Published Online: September 2021)

Open Access

(C) International Ayurvedic Medical Journal, India 2021

Article Received: 28/08//2021 - Peer Reviewed: 04/09/2021 - Accepted for Publication: 05/09/2021

Check for updates

\begin{abstract}
Periarthritis Shoulder is common in people who are middle-aged or older. As shoulder joint is the most mobile joint in the body making it vulnerable to problems, ultimately leading to restricted shoulder movements. A 67 years old male patient diagnosed with Avabahuka (Adhesive capsulitis), managed with MARMA CHIKITSA. After completion of the treatment, pain, swelling, tenderness and restricted movement of the humero-glenoid joint were reduced. As the signs and symptoms of this disease are not mentioned in Ayurvedic classics, specific treatment protocols and formulations cannot be given. The selection of drugs may differ from case to case. The treatment plan followed in this study may be adopted in future cases changing the selection of drugs based upon the necessity to obtain good results.
\end{abstract}

Keywords: Marma Chikitsa, Periarthritis Shoulder, Avabahuka, Frozen shoulder.

\section{INTRODUCTION}

As the scenario predicts this era is predominately ruled by modern Allopathic medicine, as it has made the life of a human being more comfortable with the help of research and advancement in treatment modalities. 
But in certain diseases like Periarthritis shoulder or Adhesive capsulitis modern medicine has still not found any successful remedies other than surgeries.

Avabahuka is a Vata ailment (1). All diseases occur because of an imbalance of Vata, Pitta, Kapha. The disease occurs because of the increase of one component and decrease of other in the body described in Sushruta Samhita, Nidan Sthana Adhyaya 01 as a pure vyadhi affecting the shoulder region. In Ayurveda, it is characterized by Shoshana of Amsa Bandhana, Akunchana of sira and Bahupraspandahara ${ }^{(2)}$.

Periarthritis shoulder is characterized by painful restrictions of both active and passive shoulder movements due to cause within the shoulder joint or remote. Incidences in about $2 \%$ of the general population between 40-60 years ${ }^{(3)}$. Females are generally affected. The primary cause is still unknown, and it could be idiopathic ${ }^{(4)}$. Secondary causes could be shoulder causes i. e. problems directly related to shoulder joint e. g. tendinitis of the rotator cuff, bicipital tendinitis, dislocation, fracture etc. Non-shoulder causes which are not directly related to shoulder e.g. Diabetes, Cardiovascular disease with referred pain to the shoulder, a complication of Colles' fracture.

Marma which literary means "Vital regions" of the body ${ }^{(5)}$. The Marmas are vital parts and seats of Prana or Chetna in the body. Marmas are junction places of Mamsa, Sira, Snayu, Asthi and Sandhi ${ }^{(6)}$. The Pranas are specifically situated in these Marmas by the virtue of their nature, hence a trauma to any one of these Marma invariably causes physical disturbances following their particular types. Here Bahugat Marma and Prishtha Marma were stimulated. Marma Chikitsa is the Art of treating very special vital points. It is a non-invasive technique with elaborated clinical therapy ${ }^{(7)}$.

In modern medicine, NSAID's and steroids are generally prescribed with physiotherapy and surgery is prescribed at later stages. But it remains a symptomatic approach.

If Ayurvedic approaches are intervened appropriately, further progression of the disease can be prevented. In this attempt, a case of Acromio-Clavicular Arthrosis has been successfully managed with an Ayurvedic treatment approach.

ASSESSMENT OF PAIN-VISUAL PAIN ANALOG SCALE ${ }^{(8)}$

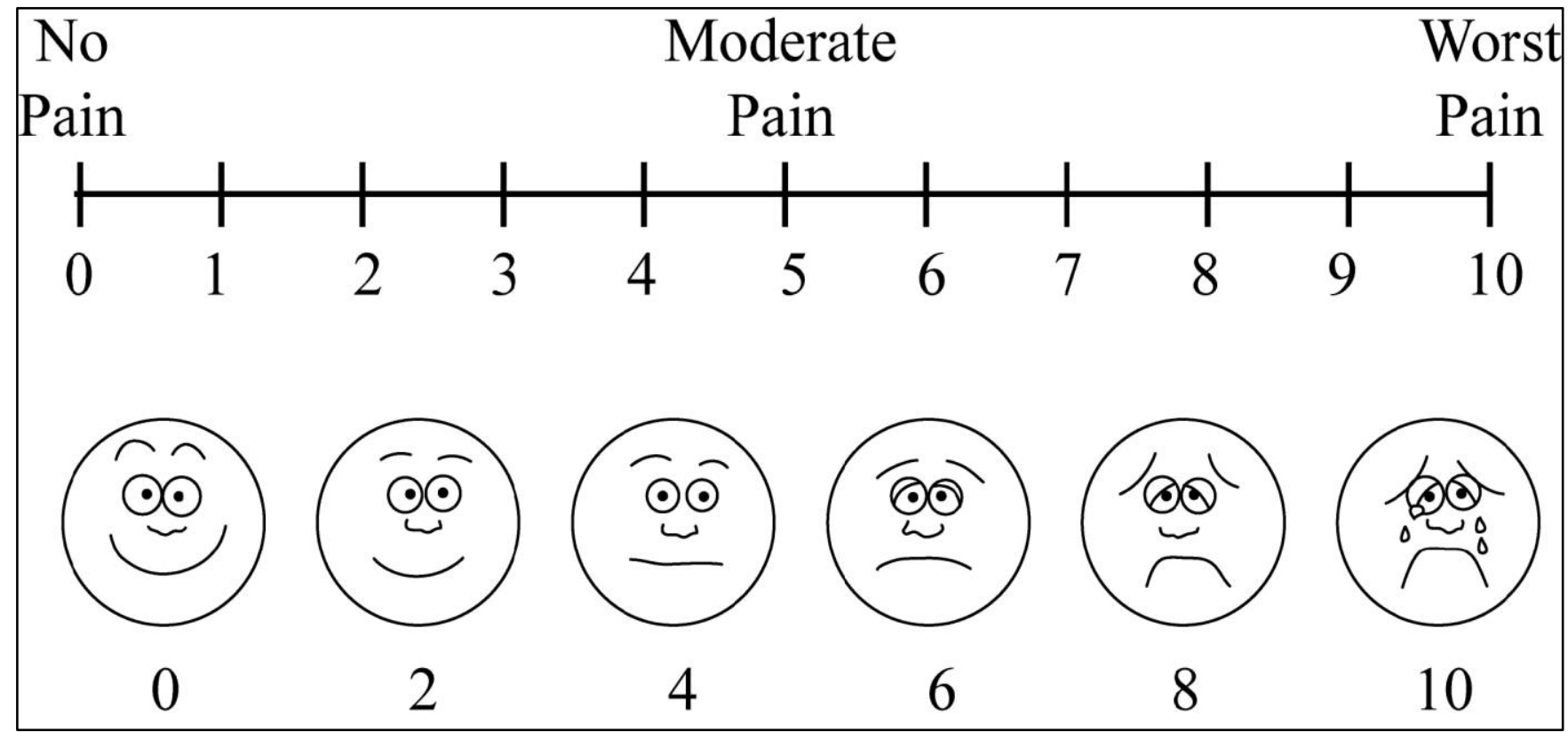




\section{TENDERNESS}

$\begin{array}{lll}\text { No tenderness } & :- & - \\ \text { Mild tenderness } & :- & + \\ \text { Moderate tenderness } & :- & ++ \\ \text { Severe tenderness } & :- & +++ \\ \text { Resticted Movements } & \\ \text { FORWARD FLEXION } & \end{array}$

Normal -180 degree

Upto $60^{\circ}$ degree or 30-60 degree - 1

Upto 90 degree or 60-90 degree- 2

Upto 120 degree or $90-120$ degree-3

Upto 150 degree or $120-150$ degree -4

Upto 180 degree or 150 -180 degree -5

\section{EXTENTION}

Normal $-50-60^{0}$

Upto $10^{0}-1$

Upto $20-2$

Upto $30-3$

Upto $40-4$

Upto 60- 5

\section{CASE REPORT}

A 67-year-old male patient visited the OPD with complaints of pain, swelling, restricted movements in the right shoulder for 1 year. The pain usually was aggravating with the movement of the shoulder and was being relieved after intake of analgesics or with hot water fomentation. Gradually the condition worsens, and the maturity of shoulder joint movements was restricted. The Cardiovascular and Central Nervous Systems did not show any specific abnormalities. Per abdomen examination was normal. Tenderness was present over the right shoulder. Restricted movements mainly in the morning were present as the patient was not able to move his right shoulder joint. X-ray right shoulder AP and lateral view were advised to the patient.

\section{Ayurveda Perspective}

Periarthritis shoulder cannot be mirrored with any particular disease condition directly that is elaborated in the Ayurveda classics. But it can be compared with Avabahuka which is a Vata Vikara.

Taking this into consideration, the patient was evaluated according to the Ayurvedic perspective. Prakriti of patient was Vata-Pitta. Though Vata and Pitta were dominating dosha in this manifestation: the involvement of Kapha dosha was also noticed. Considering the condition of the patient Marma Chikitsa was planned for 8 weeks.

In this procedure, Snehan of the parts done as to reduce Vata Vikara and Marma points which were stimulated are Shipra Marma, Talharidiya Marma, Manibandha Marma, Indravasti Marma, Kurpoora Marma, Anni Marma, Urvi Marma, Kakshadhara Marma, Ansa Marma ${ }^{(9)}$.

\section{Observation}

Melioration was seen in the patient in 8 weeks after all the modern medicines were gradually withdrawn in this period of the commencement of Ayurvedic treatment. Although the patient suffered aggravation in symptoms, they were tolerable. After completion of Marma Chikitsa for 8 weeks, the patient's shoulder pain was reduced many times. Swelling over the shoulder joint subsided and he was able to uplift his arm without any help. Now patient was able to move his joint quite freely. The patient called for followed advice every 14 days and he was on clean bill of health. By the end of treatment, no need for conventional analgesics or any inflammatory drugs were needed by the patient.

Table 1: Assessment of symptoms according to sitting therapy

\begin{tabular}{|l|l|l|l|l|l|l|l|l|l|}
\hline S. N. & Symptoms & $\begin{array}{l}\mathbf{1}^{\text {st }} \\
\text { Sitting }\end{array}$ & $\begin{array}{l}\mathbf{2}^{\text {nd }} \\
\text { Sitting }\end{array}$ & $\begin{array}{l}\mathbf{3}^{\text {rd }} \\
\text { Sitting }\end{array}$ & $\begin{array}{l}\mathbf{4}^{\text {th }} \\
\text { Sitting }\end{array}$ & $\begin{array}{l}\mathbf{5}^{\text {th }} \\
\text { Sitting }\end{array}$ & $\begin{array}{l}\mathbf{6}^{\text {th }} \\
\text { Sitting }\end{array}$ & $\begin{array}{l}\mathbf{7}^{\text {th }} \\
\text { Sitting }\end{array}$ & $\begin{array}{l}\mathbf{8}^{\text {th }} \\
\text { Sitting }\end{array}$ \\
\hline 1 & Pain & 9 & 8 & 5 & 5 & 5 & 4 & 3 & 1 \\
\hline 2 & $\begin{array}{l}\text { Restricted } \\
\text { Movements } \\
\text { Flexion }\end{array}$ & 3 & 3 & 4 & 4 & 4 & 4 & 5 & 5 \\
\hline 3 & Extention & 2 & & & & & & & \\
\hline & Tenderness & ++ & + & + & + & - & - & - & \\
\hline
\end{tabular}




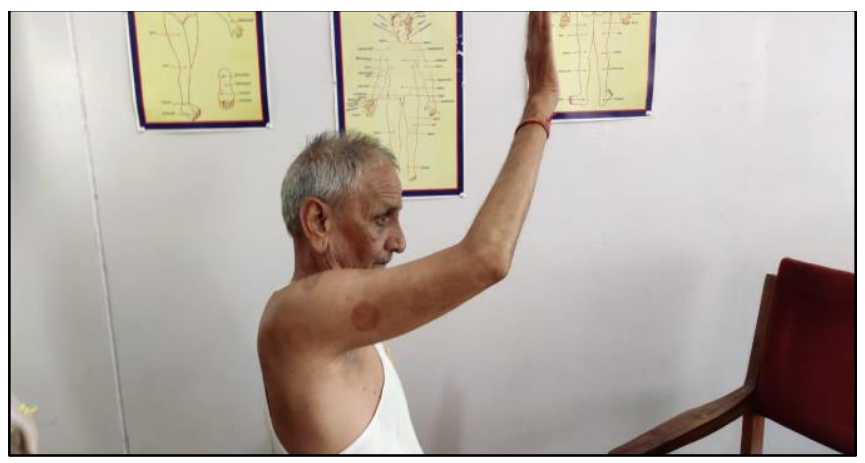

Fig. 1: Before treatment

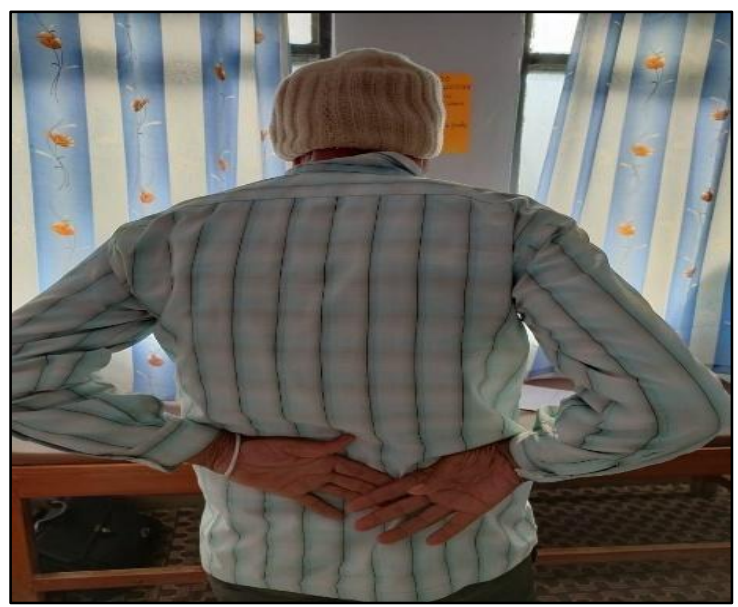

Fig. 2: After treatment

\section{DISCUSSION}

Avabahuka is described as Vata Vyadhies discussed by Acharyas. Snehan karma was done first as Snehan is Vata Shamak and moistens the area so that energy flow can take place easily. They stimulate bodily activities, increasing Agni and Pitta functions of the body ${ }^{(10)}$. Marma Chikitsa removes blocks in energy channels called Shrotas. Marma Chikitsa helps in reducing Vata dosha, bringing it to its normal path -especially Vyana Vata ${ }^{(11)}$. In this case, the effect of Marma Chikitsa was shown from the very first sitting and by the end of eight sittings, the patient has got about $90 \%$ to $95 \%$ of relief. Now patient was able to perform his daily activities.

\section{CONCLUSION}

Great Melioration was reported in the pain, stiffness and range of movements after Marma Chikitsa. The

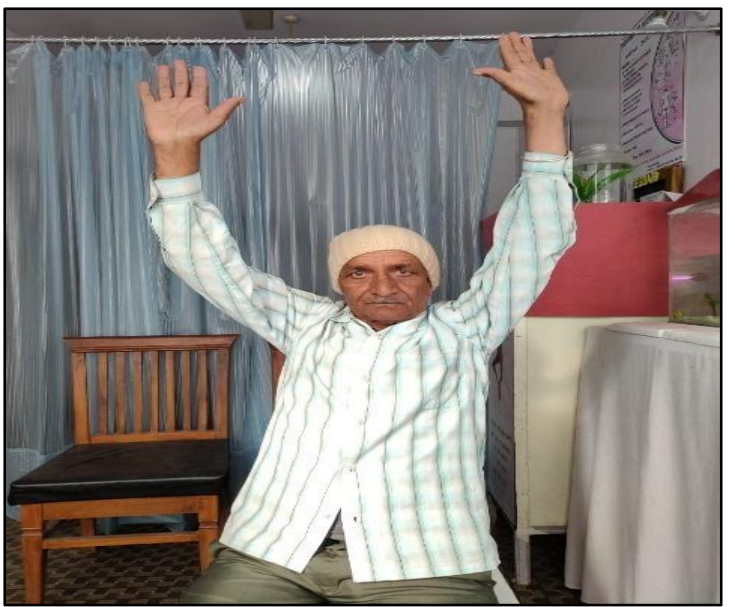

Fig. 3 After treatment

patient was treated with Marma Chikitsa. For such disease treatment in the conventional medical system has not proved satisfactory, hence Ayurveda can be used effectively. Through a single case, the report cannot prove treatment for all such manifestations, well designed clinical trials may be planned to validate the actual potency of treatment patterns and principles applied in this case.

\section{REFERENCES}

1. Shashtri, Dr Ambika Dutt. Shushruta Samhita. New Delhi: Chaukhambha Publications, 2015. 978-8189798-19-2.

2. Acharya, Dr Jyotimitra. Ashtang Sangraha. Varanasi: Chaukhambha Sanskrita Series Office. 81-7080-186-9.

3. John Ebnezar, Rakesh John. Textbook of Orthopedics 5th edition. New Delhi: Jaypee Brothers Medical Publishers, 2017. 978-93-86056-68-9. 
4. Mhaskar, Maheshwari and. Essential Orthopedics. New Delhi: Jaypee Brothers Medical Publishers Ltd, 2019. 978-93-5270-685-3.

5. Clinical Evaluation of Marma Therapy $n$ Avabahuka W.S.R. to Frozen Shoulder. Prasad, Dr S. s.l.: jmscr, 2017, Vol. 05. 22411-22418.

6. Shushruta Samhita Sharir Sthan adhyaya 6 shloka 3. Shashrti, Dr Ambika Dutt. New Delhi: Chaukhambha Publications, 2015, Vol. 1. 978-81-89798-19-2.

7. Marm Therapy in Avabahuka (Frozen Shoulder): a Retrospective Cohort. N.V. Kumari, N. Nariyal, O. Sharma, S.K. Sharma. s.1.: World J. Pharma.Res., 2018, Vol. 07 no.19. 1328-1334.

8. Vusual Analogue Scale. s.1.: Yale University, 2021.

9. Shushruta Samhita Sharir Sthan Pratekmarmanirdesha shariradhyaya shloka 06. Shashtri, Dr Ambika Dutt. Varanasi: Chaukhambha Sanskrit Sansthan, 2015, Vol. 1. 978-81-89798-19-2.

10. Dr David Frawley, Dr Subhash Ranade, Dr Avinash Lele. Ayurveda and Marma Therapy Energy Points Yogic Healing Chapter 08. New Delhi: Chaukhambha Sanskrit Prastishthan, 2019. 978-81-7084-282-8.

11. Marma Therapy. India, Nationa Health Portal Of. s.l.: NHP CC DC, 2015.

\section{Source of Support: Nil \\ Conflict of Interest: None Declared}

How to cite this URL: Neha Sharma et al: Evaluation Of Marma Point Stimulation In Avabahuka With Re-Spect To Periarthritis Shoulder. International Ayurvedic Medical Journal \{online\} 2021 \{cited September 2021\} Available from: http://www.iamj.in/posts/images/upload/2267 2270.pdf 